Revistade
Economild
Contemporâned

\title{
CHINESE INDUSTRIAL POLICY IN THE GEOPOLITICS OF THE INFORMATION AGE: THE CASE OF SEMICONDUCTORS*
}

\author{
Esther Majerowicz $z^{a}$ \\ Carlos Aguiar de Medeiros ${ }^{b}$

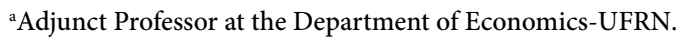 \\ ${ }^{\mathrm{b}}$ Associate Professor at the IE-UFRJ. \\ Manuscript received on 7/15/2017 and accepted for publication on 09/03/2018

\begin{abstract}
This paper examines the semiconductor's industry growing importance as a strategic technology in the modern industrial system and in contemporary warfare. It also analyzes this industry's evolution in China and the Chinese semiconductor industrial policy over the last years. We review the Chinese interpretation of the 'revolution in military affairs' and China's perception of its backwardness as well as the possibilities of catch-up and evolution in the most sophisticated segments of this productive chain through domestic firms and indigenous innovation.
\end{abstract}

KEYWORDS: China; industrial policy; semiconductors; strategic trade; technological change.

\section{JEL CODE: O2.}

* The authors thank the agencies CAPES and CNPq for the financial support, as well as Eduardo Gustini Simões, Ricardo Paes Mamede and the anonymous reviewers for their valuable comments and suggestions. All errors are our own. 


\title{
A POLÍTICA INDUSTRIAL CHINESA NA GEOPOLÍTICA DA ERA DA INFORMAÇÃO: O CASO DOS SEMICONDUTORES
}

\begin{abstract}
RESUMO: Esse artigo examina a crescente importância da indústria de semicondutores como uma tecnologia estratégica no moderno sistema industrial e na guerra contemporânea, além de analisar a evolução desta indústria na China, bem como a política industrial chinesa em semicondutores seguida nos últimos anos. Revisa-se a interpretação chinesa da "revolução nos assuntos militares" e a percepção de seu atraso tecnológico e possibilidades de catch-up e de evolução nos segmentos mais sofisticados desta cadeia produtiva através de firmas domésticas e tecnologia autóctone.
\end{abstract}

PALAVRAS-CHAVE: China; política industrial; semicondutores; comércio estratégico; mudança tecnológica. 


\section{INTRODUCTION}

Across the centuries, the control over technical progress has been an essential dimension of national power. Manufacturing and military might depend on national technical capabilities to produce and create new goods, infrastructure and weapons. Public investment in science and technology and other governmental industrial policies aimed to induce private investment in new industries and technologies have been the most persistent and predominant (although not necessarily acknowledged) lever for innovation and technical progress. Consequently, they have also been the lever for national competitive advantage creation among advanced countries. These countries systematically and politically exert control over new technologies, particularly those of dual use (civil/military), through secrecy and exclusivist policies, such as power policy.

In their efforts of industrialization, developing countries aim to reduce their technological backwardness through state-led industrial policies and fast growing investment rate. Technological catch-up by domestic firms through borrowing technologies in import substitution production or by joint ventures with transnational corporations - in areas where the barriers for importing technologies were higher - has been a common dimension of industrialization followed by fast growth in East Asian countries (homespun or export-led), and particularly in China since its opening to the international market. These technological opportunities were higher when different generations of technologies prevailed, favoring diffusion, and lower when cumulativeness concentrated innovation capacity in leading economies. Hence, industrialization through copy and borrowing technologies is easier in mature technologies, in those that property rights are not restrictive and where low labor costs are a competitive advantage. Industrialization through imitation faces growing difficulties when the technological gap decreases and the barriers for importing technologies are higher, particularly in those of dual use. In order to keep following a route of technological catch-up and preserve national autonomy, developing countries face the necessity to create a new industrial policy centered on the development of indigenous technologies exploited by competitive domestic companies in high-tech activities.

Liberalization and high trade growth took place in the world economy in the last three decades before the 2008 great crisis. In this period, the US and other "headquarter" countries organized deep global value chains (GVC) through transnational corporations (TNC) encompassing vast populations occupied in low wage countries, in productive stages in which wages were an important competitive edge. GVC led by TNC have reshaped the world division of labor. The emergence of vertical production networks was possible due to the progress of information and communications tech- 
nologies, as well as by economic liberalization in developing countries. Participating in this web led by TNC was considered, in many countries, the new industrial policy.

Since 2008, lower rates of GDP and international trade growth prevailed, and, despite the predominance of liberal thought and systematic opposition to industrial policy as a development lever, industrial policy has been "back in". In the US, Germany, France, Japan, and South Korea it never ceased to be a strong lever; in China, industrial policy achieved a high importance since the last decade. The diffusion of new technologies, particularly information and communication technologies (ICT) and their huge impact on cyber-physical industrial systems, as well as in new generations of weapons and war tactics, create systematic challenges for national power.

Electronic equipment (including electrical machines) and ICT, the greatest drivers for high-tech industrial production, have a common feature: they depend crucially on semiconductors, a high-tech input that demands complex process equipment for its production. Electronic devices, smartphones and computers - the most demanded downstream final goods - have to a substantial extent their differentiation based on the capacity and reliability of semiconductors they contain inside, and the same happens with weapons and defense sensor systems. Modern technological superiority depends heavily on ICT. The capital goods necessary to produce and process high-powered semiconductors are the highest high-tech upstream stage of modern technology. Few countries dominate this technology and few companies produce high performance semiconductors. The interactions among semiconductor manufacturing equipment suppliers, semiconductor producers and its users (electronics and ICT) form a crucial base for successful innovation in modern technologies.

China is nowadays a major producer of electronic, ICT products, and the greatest importer of integrated circuits (IC), expressing its success in the fabrication of these final goods (in stages distant from innovation and in which mature technologies predominate) and simultaneously its technological backwardness and distance from state-of-the-art semiconductor technology. The Chinese government considers this technological gap an economic and national security threat.

This paper examines the Chinese degree of backwardness in semiconductors and China's perception of its implications for technological development and for national security, as well as the industrial policies in semiconductors aimed to reduce it by developing indigenous innovation and evolving in the industry's productive chain. In addition to this introduction, this paper contains other five sections. The second section reviews the Chinese interpretation of the "revolution in military affairs", its reliance on semiconductors of high performance, the predominance of the US semiconductor transnational and the security threats associated to IC. The third section examines some new directions in the modern manufacturing system stimulated by 
ICT, highlighting the importance of the productive system's integration for productive efficiency and the Chinese analysis of its backwardness. The fourth section considers the global semiconductor industry, China's position and the US leadership based on security concerns. The fifth section regards China's backwardness and high importdependence, and some efforts to promote import substitution, create domestic leaders, investment funds and other policies aimed to acquire technology. The sixth section concludes the paper.

\section{SEMICONDUCTORS AND CONTEMPORARY WARFARE}

Semiconductors are vital for modern warfare in multiple fronts, ranging from modern weapons and battlefield operations to cybersecurity. As ICT has been driving the revolution in military affairs, chips became a building block of defense capability, being the foundation of modern systems of battle management, weapons, navigation, communication and space, deemed in modern military affairs as force multipliers (CHU, 2013). Whereas possessing leading-edge semiconductors not available to rivals can entail military-edge (PCAST, 2017), guaranteeing semiconductors' integrity is essential for the proper operations of modern weapons and those systems dependent on information that sustain national defense (CHU, 2013), including to prevent foes' access and control. Therefore, in semiconductors, detaining technological lead, preserving integrity and guaranteeing supply availability are national security concerns. As China is far from the state-of-the-art semiconductor technology and depends heavily on IC imports, all these aspects are paramount to the country.

In preparing for "local wars under conditions of informatization", the People's Liberation Army (PLA) devised a military strategy based on the concept of asymmetrical warfare, which mobilizes means beyond those narrowly deemed military to prompt attacks and defeat technologically superior adversaries, particularly through information warfare (RAUD, 2016; CHU, 2013). China has a broad and singular approach to information warfare, fusing into a single discipline the two aspects of ICT-related warfare, developed apart in the US ${ }^{1}$, namely, electronic and cyber warfare (DICKSON, 2017), focused respectively on electronic equipment and data; while extending beyond ICT to encompass "human information processing and cognitive space" (RAUD, 2016, p. 10). In ICT-related warfare, semiconductors are of utmost importance. They are also

\footnotetext{
1 "In the U.S. military, electronic warfare and cyber capabilities live in different military domains, delivered by operators who exist in different military units and who largely grew up in different career fields" (DICKSON, 2017).
} 
a target of Chinese 'Assassin's Mace weapons', which seek to neutralize technological superiority and defeat adversaries in asymmetrical warfare by attacking their greatest vulnerabilities (PILLSBURY, 2001). Hence, semiconductors are a key in its military modernization and strategy, be it to overcome or to offset its technological inferiority, in conventional or asymmetrical warfare.

Semiconductors underpin what was assessed in China's 2015 white paper on military strategy as the "new stage" of the world revolution in military affairs, encompassing: (i) the sophistication of "long-range, precise, smart, stealthy, and unmanned weapons"; (ii) the affirmation of cyber-space and outer space as the "new commanding heights in strategic competition"; (iii) the rapid evolution of the war form "to informationization"; and (iv) the military restructuring pursued by world powers, both in its material and ideal dimensions (STATE COUNCIL, 2015a). In 2015, by the creation of a new military branch, the Strategic Support Force, China demonstrated "the weaponization of broad information capabilities, plus the weaponization of outer space", moving beyond its Assassin's Mace program towards "fifth-generation warfare concepts" (FISHER apud PHILIPP, 2017).

Furthermore, the core of contemporary hard military power, precision-guided weapons ${ }^{2}$, has its accuracy and reliability - and arguably feasibility - contingent on semiconductor technology (CHU, 2013). Semiconductor technological lead can consubstantiate superiority not only in precision force, but also in electronic warfare (EW), which involves "the use of electromagnetic and directed energy to control the electromagnetic spectrum or attack the enemy" (DoD, 2017, p. 80). Leading-edge semiconductors' usage in EW entails jamming communications and radars, compromising command and control and improving stealth.

For instance, in 2016, the Department of Advanced Research Project Agency (DARPA) announced a new chip (an analog to digital converter) funded by the agency and developed in partnership with the US firm Global Foundries, described as having "a processing speed nearly ten times that of commercially available, state-of-the-art alternatives" (DARPA, 2016). Such technological advantage would provide anti-jamming capabilities to overcome threats as seen in the conflict in Ukraine, where the separatists employed EW against drones and communications "seriously hindering battlefield operations for their opponent" (GIBBONS-NEFF, 2016) ${ }^{3}$.

2 Includes "cruise missiles, ICBM [intercontinental ballistic missiles], and submarine-launched missiles" (CHU, 2013, p. 39).

3 DARPA stresses that semiconductor technology advancements enabled "three major systems" under development across the electromagnetic spectrum: the Navy's "Next Generation Jammer", to deceive radars and protect assets; the "Air and Missile Defense Radar", to search and track ballistic missiles; and the "Space Fence", augmenting small orbiting objects' detection (DARPA, 2015). 
Whilst jamming blocks the functioning of devices, directed-energy weapons can destroy semiconductors necessary for electronics' operation. These weapons seek to emulate the electromagnetic pulse (EMP) accompanying a nuclear explosion, which can irreversibly destroy semiconductors without being "generally meant to kill people" (SCHIESEL, 2003). Even if military and space chips are protected from nuclear EMP through radiation-hardening, developments in directed-energy weapons operating in diverse ranges of the electromagnetic spectrum may render them vulnerable. Furthermore, as most semiconductors used in a country are not radiation-hardened, “EMP strikes may 'deafen' and 'blind' an entire country” (CHU, 2013, p. 44). In 2017, China reported a breakthrough in directed-energy weapons: a high-power microwave weapon that can destruct electronics by compromising IC, for instance, in tanks, missiles or satellites; an Assassin's Mace that granted the researcher behind it a first prize National Science and Technology Progress Award (KANIA, 2017).

EMP strikes are not the only semiconductor-level threat. Inserting Trojan horses in IC during design or fabrication can compromise not only weapons' proper operation through performance restrictions and a diverse array of programmable failures, as kill switches, but also cybersecurity by providing a back door to outsiders bypassing all higher security levels. According to Schwartau (apud CHU, 2013), hypothetically, malicious circuitry could be inserted in military systems sold to US customers by the CIA/Pentagon, for instance, to trigger failure in a predetermined timeframe, to deviate course or even to self-destroy after used ${ }^{4}$. IC's Trojans can also target consumer electronics and critical infrastructure.

Security threats associated to IC have been the focus of a growing US concern, as the US production and the global industry have been moving to China. Previously, the industry's globalization occurred mainly among military allies, since the major global players are Japan, South Korea, Taiwan and Europe, besides the US. The US Intelligence Advanced Research Projects Activity, in 2011, launched the Trusted IC program (IARPA, 2011) to minimize the risks associated to foreign manufactured IC. According to the Senate Committee on the US Military Forces (CAS, 2011), an investigation on counterfeit electronic parts in parcel of the supply chain of the Department of Defense found 1.800 suspected cases, wherefrom a sample was tracked, 70\% leading to China. Apparently, counterfeits generally come from e-waste ${ }^{5}$.

4 In 2017, in the aftermath of Xi Jinping's visit to the US during rising tensions with North Korea, the latter's failed missile test has prompted strong speculations on possible US sabotage (SANGER and BROAD, 2017).

5 "In an illustrative case, used and remarked semiconductors were sold as new by a Chinese firm, and they were installed in unfreeze modules of a reconnaissance airship. The problem was detected during a flight test" (ITA, 2016, p.27) 
While the US have security concerns on imported semiconductors from China, even if the latter produces just a small share of global sales; the US semiconductor giants' (Intel and Qualcomm, along with the late IBM semiconductor division and Apple's recently expanding one) have been directly implicated in the Global Surveillance Program PRISM, unveiled by Edward Snowden. China, heavily reliant on imports, mostly from the US and Japan, has a major vulnerability that the CCP set to tackle through ambitious industrial policies.

\section{SEMICONDUCTORS AND MANUFACTURING MODERNIZATION}

It [the role of the IC industry] is similar to the role that the steel industry played in supporting China's earlier economic development [...] We are now in the information era [...] If China is unable to develop its IC industry, then the national goal of transforming our development model and industry structure will face a litany of problems. (YE TIANCHUN, 2014, p. 2)

As high-tech building blocks of ICT products, semiconductors are fundamental for downstream competitiveness in ICT, but also beyond. According to China's Minister of Industry and Information Technology, Miao Wei: "the scale and level of a country's IC development has become an important measurement of a country's national competitiveness and overall strength" (2014, p. 1). If semiconductors are at the ICT industry's heart, their economic importance become even more critical when informatization of manufacturing and associated services is deemed by planners as the key to their overall manufacturing (and economic) upgrade strategy, ultimately aimed at becoming the world's manufacturing leader by mid-century. The first step to this strategic goal was launched in 2015, the 'Made in China 2025' (MIC, 2025) plan or 'Manufacturing 2025'.

The plan characterizes that "the deep integration of next generation IT into manufacturing is triggering far-reaching industrial transformation", a process that would involve an industrial revolution, for "intelligent manufacturing, such as intelligent equipment and plants based on cyber-physical systems [CPS], is creating a new manufacture revolution" (STATE COUNCIL, 2015, p. 3). In this spirit, the plan focuses on raising China's capacity in innovation, industrial quality and performance, while having "the integration of the next-generation IT into manufacturing the main thread, intelligent manufacturing the main priority" and setting targets for industrial broadband penetration, digital R\&D and design tool penetration and key process control rate. Therefore, semiconductors constitute a building block for China's new comprehensive manufacturing strategy. 
Implementing sensors and IC on objects enable them, respectively, to perceive the environment, generating constant data status and position, and to compute and communicate the latter through the internet, promoting the digitalization and networking of the physical elements in the Internet of Things (IoT). The information flow generated by the diffusion of the IoT requires network and communication infrastructure as well as big data analytics, imposing the necessity for cloud computing. Also relying on semiconductors for the sensing, computing and connecting - despite networking not necessarily occurring through the Internet -, CPS encompass a virtual counterpart of machines and objects to simulate the operations of physical elements. Instead of merely monitoring objects through sensors, CPS have further emphasis on control, acting upon the environment, being especially used in critical infrastructure: "CPSs perform automated or partially automated control of physical equipment in manufacturing and chemical plants, electric utilities, distribution and transportation systems and many other industries" (COLBERT, 2017, p. 41)

Both CPS and the IoT are at the core of what has been proclaimed as the fourth industrial revolution, such as proposed by the Working Group of Germany's governmental "strategic initiative" Industrie 4.0 (KAGERMAN et al., 2013). Whether a fourth industrial revolution is on course is beyond our scope ${ }^{6}$. Of utmost importance is that the concept is being instrumentally mobilized by major states in the pursuit of comprehensive industrial policies to defend or, in China's case, to subvert the hierarchical status quo in global manufacturing production and value appropriation in a context of increased global competition. Undoubtedly, the widespread integration of ICT into manufacturing and associate services, especially by the digitalization of physical elements, is at those projects' core, extending the revolutionary effects of ICT on production further than already experienced over the last decades.

The current stream of modernization in manufacturing and associate services is characterized by the diffusion of information systems and the incorporation of productive organizational strategies enabled by ICT technologies. The central question for productive efficiency appears as its increasing dependence on the productive system's integration. "Smart" factories, cities and grid are enabled by semiconductors' implementation over physical structures, increasing their efficiency, yet exposing critical civilian infrastructure to remote cyber threats.

Over the last years, China has become the world's major consumption market for semiconductors, particularly for IC, in consonance with its consolidation as the main electronics' producer and exporter, largely resulting from typical vertical specialization in CGV led/integrated by foreign TNCs. Nevertheless, semiconductor local pro-

6 For a critical perspective on the fourth industrial revolution's discourse, see Pfeiffer (2017). 
duction and Chinese technological capabilities in IC still lag significantly behind its consumption and the technological frontier, creating obstacles for the development of Chinese-based high-end ICT goods. The lack of integration and complementarity of China's manufacturing structure has its ultimate manifestation in the enormous IC domestic production-consumption gap met by imports. For these reasons, IC became China's main net import, surpassing crude oil. Considering the increased demands posed by the manufacturing upgrade strategy of the world's factory over IC's provision, China's position as the main semiconductor consumer is prone to strengthen. Addressing these shortfalls in terms of production and technology is an emergency task for the CCP to assure the overall success of its manufacturing and economic strategy, as well as the security of intelligent factories, cities and grid.

IC, therefore, are a crucial element in the MIC's "Four Foundations" or fundamental industrial capabilities, one of them being "essential spare parts and components", whose "weak industry foundation [...] restrains Chinese manufacturing innovation and quality improvement" (STATE COUNCIL, 2015, p. 16). In these parts and in advanced materials, MIC 2025 pursues increasing the domestic sourcing to $40 \%$ by 2020 and $70 \%$ by 2025 . Not by chance, when assessing the need for achieving "breakthrough in major areas", the first sector that appears on MIC 2025 is "integrated circuits and special equipment" in the area of "next generation IT". Pursuing improvements that go from design and intellectual property in design tools to mastering advanced packaging and cultivating key manufacturing equipment providers, the plan seeks to achieve "breakthroughs in core chips that are related to national information and network security and complete electronic machine development to improve the adoption of domestic chips" (STATE COUNCIL, 2015, p. 22). Notwithstanding, MIC 2025 is not China's only policy for IC, as discussed in section 5 .

\section{THE GLOBAL SEMICONDUCTOR INDUSTRY AND THE CHINESE POSITION ${ }^{7}$}

The semiconductor industry ${ }^{8}$ is one of the world's most capital-intensive, with high $\mathrm{R} \& \mathrm{D}$ expenditures and fast technological progress 9 . The extraordinary decline in computer prices is greatly explained by the collapse of semiconductors' prices with simultaneous capacity improvement. This achievement was strongly based on tech-

\footnotetext{
7 This section is partially based on Majerowicz (2015).

8 Semiconductor devices represented a U\$ 339 billion market in 2016 (SIA, 2017).

9 An IC state-of-the-art manufacturing facility (fab) costed between U\$5 to 10 billion in 2016 (SIA, 2016a); whereas the global industry-wide ratio of R\&D expenditures to sales averaged $16 \%$ in the $2000-2014$ period (ICINSIGHTS, 2016).
} 
nical progress in machines used in semiconductors' production. Thus, the modern industrial system is formed by three high-tech sectors, semiconductors, machines at upstream and computers (and other users, as smartphones and industrial control systems) at downstream, with military demand for specific achievements in weapons performance and features largely contributing to its rise while exerting pressure over and supporting the system for technological progress, particularly through missionoriented projects. This system is split into different segments and stages according to the scale, financial and technological barriers. In this system, only the US, Japan and Germany headed all of its sectors and, therefore, are the ICT integrators. Notwithstanding, when military demand is accounted for, the US appear as the single full ICT integrator.

Whereas China is having great success in developing the downstream high-tech sector, the control over the pace of technological progress in the modern industrial system is strongly dependent on semiconductors and machines at upstream. This is highlighted by Ye Tianchun: "China has vigorously developed its IT industry, but we still import huge amounts of chips and equipment from abroad, and the pulse of development is in the hands of other people" $(2014$, p. 2$)$. The few countries that control technological progress and integrate the modern industrial system contrast with the diversity of those involved in semiconductor production, many being mere sites for TNC's operations. Currently highly fragmented, the semiconductor industry was one of the first to become global. The large variety of semiconductors components is subsumed in two industrial segments: IC and optoelectronics-sensor-discrete devices. Integrated circuits or chips, the "brains" of electronics, form the bulk of the semiconductor market.

The IC value chain is divided in five stages: conception; design; the front-end of fabrication or merely fabrication; assembly, packaging and testing (AP\&T), the backend of fabrication; and customer services (GUTIERREZ and LEAL, 2004). Conception and design are skilled labor-intensive. Initially executed manually, they started being performed using IC's project software, the electronic design automation (EDA) tools, in the early 1980s.

Fabrication is characterized by the intense usage of machinery. Front-end plants (fabs) impose very high capital requirements - involving manufacturing operations among the world's most complexes - and "constant facility improvement to keep up with technological advances", while "successful manufacturers require high capacity utilization (90 percent) and large-scale operations" (SIA, 2016a, p. 5).

Finally, AP\&T, the simplest productive phase, is unskilled labor-intensive, "although still relatively technologically sophisticated" (GAO, 2006, p. 4). According to Gartner, in the global industry only $6 \%$ of workers employed in the back-end had 
engineering diplomas, contrasting to $24 \%$ in fabrication and $85 \%$ of higher educated workers in design (WANG and WANG apud MAYS, 2013). Despite automation in AP\&T and advanced packaging technologies, fabrication's high sophistication degree makes back-end machinery look relatively cheap.

Originally, all enterprises were integrated device manufacturers (IDM), comprising the entire productive process. IDM remain important contemporarily, and the industry's leaders, Intel and Samsung, are both IDM. The IC industry's strategic status informed its delocalization process, which, roughly, preserved in the headquarter economies the higher value-added stages associated to technological development and control, and the fabrication of products in the technological frontier. The fragmentation of the IC value chain started with AP\&T delocalization to Asia. In the wake of this intra-firm offshoring process, a new enterprise type emerged, the semiconductor assembly and test services (SATS), commercializing their productive capacity and enabling back-end activities' outsourcing.

The most significant value chain fragmentation, revolutionizing the industry's entrepreneurial organization, occurred only with the advent of EDA tools. They enabled fabrication's detachment from design, affirmed by the emergence of fabless - firms without fabs and AP\&T plants -, pure-play foundries - enterprises detaining fabs that commercialize their productive capacity to others - and design houses (MILLARD et al., 2012).

Considerations for relocating front-end are distinct from back-end. In fabs, labor is just $5 \%$ to $10 \%$ of total costs (SYKES and YINUG, 2006). Front-end offshoring tends to occur in less sophisticated ICs, maintaining home those plants with the latest process technologies and most sophisticated products, while in AP\&T offshoring generalizes despite the product. IDMs' recalcitrance to offshore the most advanced fabs, sometimes limited/prohibited by governments, can be related to fabrication's importance to innovation and to technological learning in IC. Regarding the design segment and R\&D, whereas delocalization may respond to talent availability and to cheaper skilled labor, the proximity to consumers is an important parameter, enabling to better respond to client specifications and adapt products to particular markets. $\mathrm{R} \& \mathrm{D}$ labs holding fabs that run new process technologies, however, are prone to remain home.

To integrate in this GVC beyond assembly, a latecomer must count with domestic efforts to develop fabrication as well as significant talents and skilled laborers availability to carry on design, whereas having a sizeable domestic market may open integration roads unavailable to small economies. Initially assembly sites, some Asian economies, notably South Korea and Taiwan, managed to move-up in the value chain, whilst others, such as Malaysia, have not. China's main roles to the global industry 
contemporarily are of prime consumer and assembler of ICs, with foreign firms' predominating in both supply to and production in China.

Although global, the semiconductor industry is controlled by a handful of military allied economies. The role of military requirements and support were particularly important to the industry's rise and geographical dispersion. Industrial policy and strategic trade were fundamental for its birth in the US and the subsequent entrance of the major world market players. They were also paramount to defend industrial leadership in periods of increased international competition. In the semiconductor industry's evolution, governmental support has been decisive.

Despite US commercial firms inventing the transistor in 1947, and the IC, prototyped in 1958 (Texas Instruments) and produced for commercialization in 1961 (Fairchild) (MILLARD et al., 2012), the US governmental support, particularly from the military, was vital for the industry creation. The government provided the essential parameters for the rise of semiconductor supply and demand. It posited and prioritized a technological necessity, funded initial $\mathrm{R} \& \mathrm{D}$ and the first pilot production, assisted $\mathrm{R} \& \mathrm{D}$ and production engineering, and assured military procurement at lucrative prices (NRC, 2012; RASIAH, 2010; MORRIS, 1990). Initially, R\&D came to serve the need for radar precision in the Second World War against Germany, funded mainly by the US Signal Corps, whereas public funding extended beyond to encompass $40 \%-45 \%$ of the US industry R\&D from late 1950s to early 1970s (NRC, 2012; RASIAH, 2010).

Morris (1990) points the assured military market as "perhaps the most crucial factor in the development of the industry" (p. 73). Guaranteeing demand at lucrative prices stimulated private firms' pursuit of IC development and provided the market for semiconductors that industrial and commercial consumers could not at stages of high unit costs, while giving enough demand extent for generating productive economies of scale in the 1960s, necessary to reduce prices and boost industrial/commercial demand (MORRIS, 1990; NRC, 2012). Such advantage was unavailable to firms in other countries, which also suffered from their governments' "comparatively little support" (MORRIS, 1990, p. 73).

However, the US would face challenges from Japan. Successful industrial policies allied to the unilateral openness of the US market to Japan, extending to the Japanese the conditions for productive economies of scale, led Japan to the industry's leadership in the 1980s. The US share of worldwide semiconductor market declined from $60 \%$, in the early 1970 s, to $51 \%$ in 1982, and 35\% in 1989. At the same time, Japan's rose respectively from $15 \%$ to $35 \%$ and to $51 \%$ (JOHNSON, 1991). First felt by the late 1950 s, in the form of consumer electronics' imports, Japan's competition prompted US semiconductor firms' response by offshoring assembling to low wage countries in the early 1960s (MORRIS, 1990), especially to Asia, kick-starting the formation of the GVC. 
Counting with long-term bank loans at low interest rates, a protected market and a well-funded research consortium led by the government, Japanese firms developed as IDM (NRC, 2012; BINGHAM, 1998). Japan entered and dominated the leadingedge memory market, in which low technological cumulativeness due to "technological discontinuities between generations" and mass production made it more prone to technological catch-up ${ }^{10}$ (CHANG et al., 2015, p. 27), whereas the latter feature made this segment a driver for process technology in the industry (NRC, 2012). Generally in a same keiretsu, semiconductor firms close ties with semiconductor manufacturing equipment (SME) suppliers were crucial for building a strong SME industry, which became the world leader. Differently, US semiconductor firms constantly changed suppliers and transferred the costs of demand volatility to the latter (BINGHAM, 1998).

The US semiconductor industry called for government support through the lobbying and public relations of the Semiconductor Industry Association (BINGHAM, 1998). Meanwhile "a defense task force warned, in 1987, that a dependence on foreign suppliers for state-of-the-art chips for weapons was an 'unacceptable situation' because it would undermine the U.S. military strategy of maintaining technological superiority” (NRC, 2012, p. 325). As a result, the US created SEMATECH, a governmentindustry R\&D consortium, half-funded by DARPA and involving major US firms. By a legislative rule, excepting "precompetitive" research from anti-trust laws (BINGHAM, 1998), SEMATECH developed an industry-wide detailed coordinating technological roadmap for accelerating the adoption of new technologies. Moreover, the US pushed Japan to open its market through the bilateral first Semiconductor Trade Agreement (1986-1991), also aimed to ban and monitor Japanese "dumping practices" (OTA, 1991). US firms were targeted to climb from $9 \%$ to $20 \%$ of Japan's domestic market (JOHNSON, 1991), while the US declared that "dumping practices" continued in 1987, imposing sanctions that were followed by Japan reducing dynamic random access memory (DRAM) production and prices increasing (OTA, 1991).

By the early 1990s, the US was able to regain leadership, though not without costs. Many of its large firms had exited the DRAM market, maintaining just Micron as a top player, and losing its commercial firms in the critical/highest technological SME, the photolithography tools, whose persistent improvements enabled IC manufacturers to decrease chips' size, while augmenting their performance and functionalities (ATTA and SLUSARCZUK, 2012).

Nevertheless, the US actively enabled the conditions for the emergence of competitors to Japan. By handling the Japanese government and repressing its semiconductor

${ }^{10}$ Contrasting to high cumulativeness and small-batched production in logic favoring Intel dominance (CHANG et al., 2015). 
industry, a space was created for the ascertaining of South Korean chaebols in memory chips, with Samsung becoming the segments' dominant enterprise. To counter Cannon and Nikon, the US government allowed US firms' acquisition by and partnership with Dutch ASML, transferring to the latter the most advanced photolithography technologies and providing access to US national defense laboratories (ATTA and SLUSARCZUK, 2012). ASML became the segment's world leading enterprise, while providing early access to the newest photolithography tools to US firms ${ }^{11}$. Current progresses in photolithography tools by ASML are still contingent on US governmental labs' developed technology. Although the US lost its commercial leg, they can still operate as system integrators insofar as they dictate technological change in such crucial equipment.

Starting in the mid-1960s, Korea and Taiwan became sites for TNC semiconductor assembling, particularly US', supported by policies to attract FDI and to increase exports (OTA, 1991). Whereas during the 1970s industrial policies aimed to foster an indigenous semiconductor industry in Korea, they more importantly gave rise to the economically concentrated and dominant chaebols in electronics. The latter would target entering in the DRAM market in the 1980s, to which scale and vast financial resources were imperative (KIM, 1996).

To escape DRAM's intense competition, Taiwanese industrial policy targeted customized chips to which design capabilities were essential (OTA, 1991). The main strategy of Taiwan was to establish the public Electronic Research and Service Organization (ERSO), which would partner with foreign firms to acquire technology, and help create private domestic firms which would receive technology from ERSO. The Radio Corporation of America partnership with ERSO was cornerstone to the creation of the United Microelectronics Corporation, and the subsequent partnership with Philips to TSMC.

While SATS had already emerged in Taiwan, allowing TNC to externalize assembling, TSMC, created in 1987, was the first foundry fully commercializing its productive capacity, without developing/selling their own IC. Such foundries' consolidation enabled fabless' proliferation, which could then enter the industry circumventing the entry costs of fabs. Moreover, to deal with excess demand and particular lines of integrated circuits, IDM started to outsource to foundries (GAO, 2006).

\footnotetext{
11 "Manufacturers, however, can make only one or two leading-edge tools per month. The highest profit margins for IC products come immediately after an advance occurs in lithography technology. Once the improved lithography tools become more widely available, the ICs they produce become commodity items with thin margins. [...] Tool suppliers use this as leverage to reward their largest and most loyal customers" (ATTA and SLUSARKZUC, 2012).
} 
In 2016, among the forecasted top-20 semiconductor firms in sales revenues, the US held eight enterprises, including world leader Intel; Japan, Europe and Taiwan had three each (TSMC as $3^{\text {rd }}$ ); Korea had two (Samsung as $2^{\text {nd }}$ ); and Singapore had one; whereas 12 firms were IDM, five fabless and three foundries (ICINSIGHTS, 2016c). While China held no position, especially for lacking a large IDM, it became the main semiconductor consumption market, representing $60.6 \%$ of the global market ${ }^{12}$ in 2016 (PWC, 2017a), and the major semiconductor assembly base, the lowest value-added stage. These facts emanate from China's capacity to attract FDI in the unskilled labor-intensive assembling of both electronics and semiconductors. However, since mid-2000s, China has had domestic firms among the top 10 of each GVC's segment (fabless, foundries and SATS).

Figure 1 - Market shares of global semiconductor sales of final devices by headquarter seller (IDM and fabless only)

\begin{tabular}{|c|c|c|c|c|}
\cline { 2 - 5 } \multicolumn{1}{c|}{} & 2013 & 2014 & 2015 & 2016 \\
\hline US & $51 \%$ & $51 \%$ & $50 \%$ & $48 \%$ \\
\hline South Korea & $16 \%$ & $17 \%$ & $17 \%$ & $17 \%$ \\
\hline Japan & $14 \%$ & $12 \%$ & $11 \%$ & $11 \%$ \\
\hline EU & $9 \%$ & $8 \%$ & $9 \%$ & $10 \%$ \\
\hline Taiwan & $6 \%$ & $7 \%$ & $6 \%$ & $7 \%$ \\
\hline China & $4 \%$ & $4 \%$ & $4 \%$ & $5 \%$ \\
\hline
\end{tabular}

Sources: Authors' elaboration based on data extracted from SIA $(2014,2016,2017)$ and ITA (2016).

In 2016, considering only the sales of final semiconductor devices (fabless/IDM) Chinese headquartered firms held a mere $5 \%$ of the world semiconductor market (SIA, 2017). Although responsive when their leadership was threatened, the US largely condescended to Japan's and later Korea's and Taiwan's industrial policies - counting with US market unilateral openness and technological transfer - for their geopolitical alliance and role as bases for US military containment of Chinese influence on the region. Since 1989, the US has kept export controls to China. The Wassenaar Arrangement has served the US practice of limiting SME exports to China at least at two generations behind US state-of-the-art (GAO, 2002; LI, 2016). Taiwan has severely limited the scope of semiconductor Taiwanese companies' and citizens' activities in the mainland ${ }^{13}$, focusing until recently in prohibitions to outward investments, especially

\footnotetext{
12 Estimates based on Chinese statistics, different form international standards, see PwC (2016).

13 See Chu (2013).
} 
in design and manufacturing. Nonetheless, due to the mainland's market importance, Taiwan increasingly relaxed restrictions; while global competition has made US export controls circumvented by acquisition from Europe and Japan (MAYS, 2013).

China's ambition to have a world-class semiconductor industry and the vast funds and multiple tools being mobilized for it represent an economic and military threat to the US and the major players. If China acquires a dominant market share, US commercial threats are unlikely to be effective in disarming its industrial policy and repressing its industry, as China is the largest semiconductor market and the US its largest supplier.

\section{CHINESE IC INDUSTRIAL POLICY}

China had an auto-sufficient but technologically backward semiconductor industry, granted strategic status in the Maoist period, with the creation of the Electronic Industry Ministry (RASIAH et al., 2008). The country pursued, until 1980, the autonomous development of semiconductor technology for military use, developing its first semiconductor in 1956 and its first IC in 1964, with R\&D undertook by state labs and IC manufacturing by state-owned factories (LI, 2016). When reform and opening took place, China was far behind the international semiconductor mainstream: "Being backward and incompatible with the mainstream standard, the indigenously developed technology was gradually abandoned" (LI, 2016, p. 196). In regards to manufacturing process technology, China was five generations behind the US state-of-the-art in 1986 (GAO, 2002).

Through the 1980s and 1990s, China tried a series of policies to develop the semiconductor industry, including importing entire production lines by state-owned enterprises (SOE). As the Chinese consumption market for semiconductors started to grow beyond its productive capabilities, triggering TNC's interests, the CCP allowed their entrance through joint-ventures with SOE (LI, 2016). In 1989, China produced 114 million IC units and consumed 300 to 400 million; in 1995, this gap was of 4.5 billion units, representing U\$ 1.7 billion (SIMON 1992 apud LI, 2016; SIMON,1996 apud LI, 2016). In this context, China launched Project 909, which included the attempt to build as an IDM a new indigenous firm Shanghai Hua Hong Group in joint-venture with Japanese NEC in 1997, a frustrated attempt as the firm failed to become an IDM and established as a foundry (LI, 2016).

It was only in the 2000s that China would become deeply integrated into the semiconductor GVC, in the context of its World Trade Organization accession. Successive industrial policies have been implemented since 2000, with varying degrees of success over each GVC segment. Overall, these policies contributed to increase China's participation in the semiconductor industry's revenues from $2 \%$ to $17.8 \%$ of the global 
industry from 2000 to 2016 (Figure 2). Such a significant participation in the global industry, compared to the mere $5 \%$ held in 2016 by China-based firms in the world sales of final devices, on the one hand, reveals the importance of foreign firms in China's semiconductor production; one the other hand, it accounts for the contribution of SATS and foundries for the overall industry revenues.

The inaugural policy landmark was the 2000 State Council Rule 18, which fostered the entrance of foreign-owned semiconductor firms, reduced SOE' role and provided tax incentives (ERNST, 2015). The Rule promoted favorable tax treatment to IC domestic firms, considered as those located in China, encompassing foreign firms (PWC, 2004), as well as government investment in R\&D, education and infrastructure (CS, 2016).

Chinese low unskilled labor costs acted as a strong magnet to global electronics' manufacturers and semiconductor AP\&T, the latter also attracted by electronics producers' proximity. Both productive migration trends carried uninterruptedly throughout the 2010s. In 2009, China became the world's main base for semiconductor AP\&T in factory floor space, ranking first in the 2010s also in facilities, production value and employees (PWC, 2017, 2017a). All main IDM and SATS have AP\&T plants in the mainland. In 2017, China had three firms among the top 10 SATS worldwide: Jiangsu Changjiang Electronics Technology $\left(4^{\text {th }}\right)$, Tianshui Huatian Microelectronics $\left(7^{\text {th }}\right)$ and Tongfu Microelectronics $\left(8^{\text {th }}\right)$ (PWC, 2017a). Therefore, the segment is a mature industry in China with globally competitive domestic firms in outsourced services.

Figure 2 - The Semiconductor Industry in China (2000/2016)

\begin{tabular}{|c|c|c|c|c|c|c|c|c|c|}
\hline & 2000 & 2003 & 2005 & 2007 & 2009 & $2011^{\mathrm{b}}$ & 2013 & 2015 & 2016 \\
\hline Semicondutor revenues (US bn) & 5 & 8.3 & 16.1 & 27.4 & 29.2 & 51.4 & 65.8 & 89.3 & 99 \\
\hline As world share ${ }^{a}$ & $2 \%$ & $5 \%$ & $6 \%$ & $9 \%$ & $7.5 \%$ & $9 \%$ & $12 \%$ & $16.2 \%$ & $17.8 \%$ \\
\hline OSD revenues (US bn) & 2.8 & 4 & 7.5 & 11 & 12.9 & 21.5 & 25 & 31.8 & 33.7 \\
\hline self-sufficiency ratio & - & - & - & - & - & $106 \%$ & $110 \%$ & $101 \%$ & $101 \%$ \\
\hline IC revenues (US bn) & 2.2 & 4.2 & 8.6 & 16.5 & 16.2 & 29.9 & 40.8 & 57.5 & 65.3 \\
\hline self-sufficiency ratio & $19 \%$ & $17 \%$ & $19 \%$ & $22 \%$ & $19 \%$ & $24 \%$ & $27 \%$ & $33 \%$ & $36 \%$ \\
\hline $\begin{array}{l}\text { Semi AT\&T ( } \% \text { of world } \\
\text { production value) }\end{array}$ & - & $9 \%$ & $12.6 \%$ & $15 \%$ & $20.3 \%$ & $30.8 \%$ & $40.8 \%$ & $33 \%$ & $36 \%$ \\
\hline Semi fab (\% world fab capacity) & - & $6.3 \%$ & $7.4 \%$ & $8.7 \%$ & $9.6 \%$ & $10.8 \%$ & $10.9 \%$ & $12.7 \%$ & $14.2 \%$ \\
\hline IC desing revenues (US bn) & 0.13 & 0.54 & 1.52 & 2.97 & 3.95 & 8.14 & 13.15 & 21.09 & 24.75 \\
\hline as $\%$ world fabless & - & $2.5 \%$ & $4 \%$ & $6 \%$ & $7 \%$ & $10 \%$ & $17 \%$ & $25 \%$ & $27.4 \%$ \\
\hline
\end{tabular}

Notes: (1) Overscript (a) represents a series break in 2009 and (b) represents series breaks due to revised industry statistics. (2) Semi stands for semiconductors; OSD, for opto-sensor-discrete; IC, for integrated circuits; AP\&T, for assembly, packaging and test. (3) Semiconductors is the aggregate of the OSD and IC segments. (4) Self-sufficiency ratio is the ratio of production over consumption in China. (5) All data include both foreign and domestic firms. (6) IC design revenues for 2016 were obtained from PwC (2017a) by multiplying the percentage of design revenues in overall industry revenues, while the percentage over world fabless revenues was obtained dividing PwC data by ICinsights (2017) worldwide fabless revenues. Source: PWC (2004, 2007, 2008, 2010, 2012, 2015, 2017, 2017a), ICinsights (2017) 
In the early 2000s, the $10^{\text {th }}$ Five Year Plan prioritized developing a domestic IC foundry industry: "pure-play foundries SMIC and Grace (now Hua Hong Semiconductor) were both founded in 2000 and XMC was founded in 2006" (ICINSIGHTS, 2016a). Including the opto-sensor-discrete segment, China's share of world semiconductor fab capacity grew from $1.5 \%$ in 2001 to $7.4 \%$ in 2005 (PWC, 2016). During the period, few foreign IDM had fabs in China (PWC, 2006), and IC fabrication was mainly propelled by governmental efforts in creating domestic foundries.

However, Chinese headquartered firms' share of the pure-play world foundry market peaked in 2006-2007 in 13.3\% and dropped, stagnating around 8-9\% in the 2010s, despite support since the 1990s (ICINSIGHTS, 2016b; CS, 2016). Chinese leading foundry SMIC has been for the last years consistently two generations behind the leading-edge (ERNST, 2015). The main challenges to Chinese firms' rapid entry would be the high capital requirements and technological gap, acquiring/guaranteeing customers to newly created capacity and developing across the IC ecosystem for implementing new process technologies each two years (CS, 2016).

In the early 2000s, the design sector also started to develop, becoming the major Chinese IC segment in revenues in 2016 (PWC, 2017a). The government stimulated the emergence of fabless to create demand for homegrown foundries. Even if most of current top domestic fabless were created in the 2001-2004 period (ICINSIGHTS, 2016a), foreign firms then preponderated in China's design sector, aiming to adapt products to the growing domestic market (PWC, 2004). China's fabless sector, particularly homegrown firms, has bloomed since $2005^{14}$. As China became the main semiconductor consumption market in 2005 (PWC, 2006) and has geared into becoming the largest PC and smartphone markets (the latter the major demand driver for IC since 2011), the CCP promoted the development of domestic electronics firms, as Huawei, Lenovo and ZTE, while pursuing the implementation of domestic standards. Chinese $3 \mathrm{G}$ and $4 \mathrm{G}$ standards and the licensing policy to SOE telecom providers leveraged China's large domestic market to develop domestic IC design firms' technical capabilities, particularly benefiting Spreadtrum, RDA and Taiwanese Mediatek, while enabling the country now to "co-shape international mobile telecom standards" (ERNST, 2015, p. 29).

The pursuit of domestic standards was catalyzed in 2006 by the Medium and Long-Term Plan for Science and Technology Development (2006-2020), in whose core lies the concept of indigenous innovation and self-reliance rhetoric, aiming to reduce technological dependency, especially on the US and Japan, seen as security threats (ERNST, 2011). Indigenous innovation, however, does not equal to domestic

${ }^{14}$ Growing from $2.5 \%$ to $27.7 \%$ of the world fabless market between 2003 and 2016 (Figure 2). This growth also started to attract foreign foundries eager to tap the market, breaking a certain reluctance of IC manufacturers (and governments) to construct advanced fabs offshore. 
R\&D, having an important role for technology import, as expressed in Chinese telecom standards, carrying huge chunks of foreign intellectual property. According to Ernst (2011), indigenous innovation encompasses original innovation (patent leading, or just innovation), "integrated innovation" (similar to technology diversification), and "re-innovation" (similar to incremental innovation), which "building on imported technologies, 'incremental innovation' seeks to exploit as much as possible the potential of a given "design", by introducing relatively minor changes to an existing product or process" (p. 25). Regarding semiconductors, the Ministry of Industry and Information Technology asserted in 2006 targets for self-sufficiency ratios in IC higher for those in information and national defense security than in communications and digital household appliances -, as well as to "basically achieve self-sufficiency in the supply of key products" (MIIT apud Ernst, 2011, p. 24).

Despite these policies, ensued by the 2011 State Council Rule 4 substituting 2000's Rule 18, the Chinese consumption-production gap skyrocketed (Graph 1). China's semiconductor consumption grew from $18.5 \%$ of the world market, in 2003 , to $56.6 \%$ in 2014 (PWC, 2017). The consumption-production gap rose from U\$20.8 billion in 2003 to U\$120.1 billion in $2014^{15}$ (PWC, 2016). Despite this large gap, an expanding demand is fundamental for entering other GVC segments beyond assembling. A restricted domestic market was an important factor to Malaysia's failure in significantly developing manufacturing and $\mathrm{R} \& \mathrm{D}$, when the country was the main world base for semiconductor assembling, before China overtaking it.

Foreign firms captured most of the growth of China's semiconductor consumption market. In 2014, all top 10 suppliers of China's market were foreign, namely, Intel, Samsung, SK Hynix, Qualcomm, Toshiba, Texas Instruments, STMicroelectronics, AMD, Freescale and Renesas (PWC, 2016). In this context, Snowden's 2013 revelation of PRISM, involving Intel and Qualcomm, might have catalyzed the promulgation of the 2014 Guidelines for the Promotion of the Development of the National IC Industry (hereafter, the Guidelines).

The 2014 Guidelines have set ambitious targets for China's IC industry development, aiming not to move-up/upgrading in the GVC - which implies the concomitant entry/exit in higher/lower value-added productive stages -, but to promote import substitution, strengthening all stages. The central issue for China's technological progress and value appropriation is not merely GVC product "upgrading". The mainland already has significant insertion in all semiconductor GVC segments (Figure 2), largely manifesting that "vertical integration between multinational corporations has created an industry ecosystem, and Chinese domestic companies can only passively follow behind", whereas "high-level chips are mostly manufactured outside of China" (WEI, 2014, p. 4).

15 Even if the "self-sufficiency" ratio grew from 17\% in 2003 to $29 \%$ in 2014 (PwC, 2016). 
Graph 1 - The Chinese IC gap (in U\$ billion)

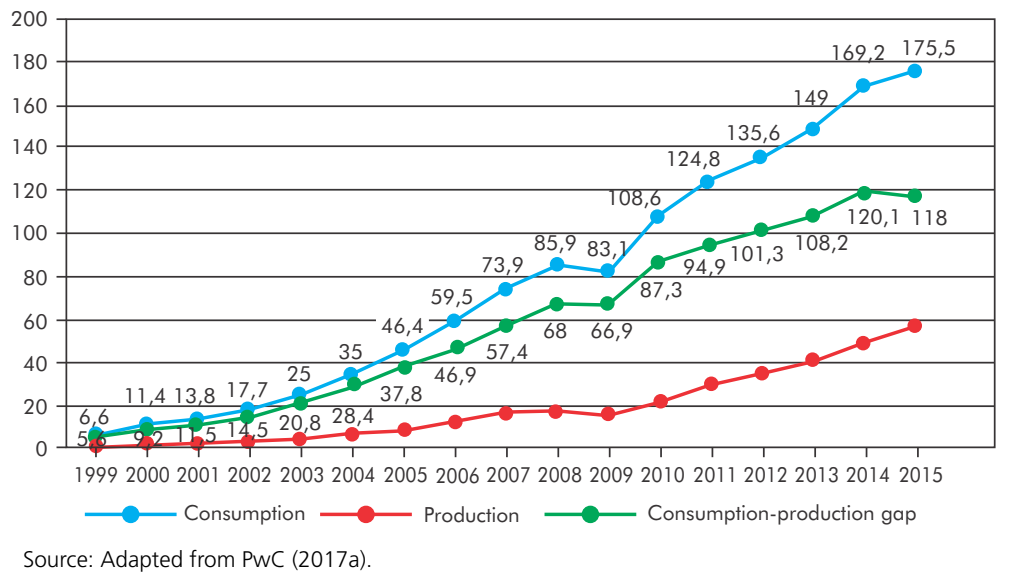

To reach the technological frontier and to vie for the control over the direction and pace of technological progress - translated into higher than average profits and, therefore, larger shares of value appropriation in the CGV -, China seeks to domestically integrate (i) all IC industrial stages along with (ii) the downstream and the upstream high-tech sectors of the modern industrial system. In promoting the latter, the Guidelines have put greater emphasis at downstream, due to the sector's advanced stage of development compared to the incipient development upstream. One of the Guidelines' basic principles is to "build an industrial chain consisting of "integrated circuit chips, software, whole units, systems, and information services" (STATE COUNCIL, 2014, p. 2).

China has identified the problem with IC insufficient production (productionconsumption gap) "as the critical roadblock to catching up and forging ahead across a broad range of China's leading industries" (ERNST, 2016, p. 9). Insufficient production and technology are inextricably intertwined, in as much as the mastery of a technology and innovation depend on the essential process of learning in production, particularly in manufacturing sectors in which "manufacturability of new products is the most critical step in the innovation chain" (CHANG and ANDREONI, 2016, p. 20). Therefore, the Guidelines set targets for industry revenues and technology in all industry segments, equipment and material. In 2020, China plans to achieve 2014's state-of-the-art manufacturing process technology in mass production $(16 \mathrm{~nm} / 14 \mathrm{~nm})$, international leading-edge in AP\&T and in key design areas (smartphones/network communication/cloud computing/IoT/big data) and to produce key equipment and materials (STATE COUNCIL, 2014), whereas MIC 2025 set self-sufficiency ratios for 2020 in $40 \%$ and $70 \%$ for 2025. 
The ultimate goal is to achieve advanced international level in the IC industry's main stages by 2030, with few enterprises in the top global firms (STATE COUNCIL, 2014). The goals, however, are much less ambitious in equipment and materials, the upstream sector, which is China's most backward segment, the hardest to enter and yet the most fundamental for controlling technological progress' pace. In SME, just the US, Japan and Europe are important global players. In Tianchun's (2014) view "China does not have to be competitive in all critical areas of equipment and materials - but we must develop a few key products in order to give our industry the confidence to engage in global technological cooperation and dialogue" (p. 3). Notwithstanding, he recognizes that without the upstream sector China will be "unable to grasp the industry's decision-making power" (p. 3), providing intelligibility to the export controls these goods are still submitted to.

The Guidelines have already qualitatively improved Chinese smartphone suppliers' global competitive position by raising homegrown IC design capabilities (CHINA DAILY, 2017). According to Ernst (2016), an adjustment was implemented to China's semiconductor industrial policy by the MIC 2025 and supporting policy documents, with a view to diversify China's semiconductor products aiming to fulfill the targets as the demand-pull from smartphones decelerates, including a push to enter in memory and industrial-end market semiconductors. China achieved its 2015 revenue target and is likely to fulfill the $40 \%$ self-sufficiency ratio by 2020, for in 2016 the ratio was $36 \%$, up from 17\% in 2001 (PWC, 2017). Moreover, the production-consumption gap shrunk absolutely in 2015-2016, which had only happened in 2009 since China's GVC integration (PWC, 2017a). Whereas technology targets are contingent to Chinese firms, industry's revenues and self-sufficiency ratios benefit from foreign firms' operations. The latter play a key role in China's strategy, providing technological transfers and reducing its imports.

To those ends, China has created large public and private investment funds - the latter with significant government influence -, expected to reach U\$150 billion over the next decade (PCAST, 2017). In 2014-2015, the central and local governments set the National IC Fund and several regional funds, respectively. These resources have been employed to integrate the IC chain - as Tsinghua Unigroup fund's acquisitions aiming to build an IDM ecosystem - and to pursue domestic consolidation and investment in domestic leaders, with a view to increase firms' capacity to engage in large R\&D expenditures, upgrade facilities and contour fabrication's high capital requirements and longer investment maturation (CS, 2016; EUCCC, 2017). Consolidation also seeks to augment China's market power vis-à-vis international suppliers in the GVC. 
Furthermore, the funds served an aggressive pursuit for foreign acquisitions ${ }^{16}$, seeking to obtain critical technology. Such road has been quickly blocked in the US - by the Commission on Foreign Investment in the US -, South Korea, Taiwan and growingly in the $\mathrm{EU}^{17}$ and Japan, the latter under substantial US pressure. However, the blockage cannot impede technology import. Ernst (2016) highlights that at least Tsinghua developed sophisticated strategies to acquire critical technology, while several leading global firms would be betting on Chinese policies' success: "in fact, U.S. and other foreign firms are quite explicit that they might accede to Chinese demands to transfer technology and form joint ventures with its firms, if only they could expand or at least sustain their share of the China market" (p. 18-19).

In mediating the access of foreign firms to China's market, the government has been using a series of tools - such as procurement, security legislations, anti-monopoly law and propaganda - to acquire technology, disclose information, localize foreign firms, reduce royalty payments and substitute domestic for foreign technology where domestic capabilities exist. The use of these tools imbricates national security and economic reasons. After PRISM revelation, the Chinese government has drafted/passed, in 2015/2016, the National Security Law, the new banking and insurance regulations, the Cybersecurity Law and the Antiterrorist Law, emphasizing the use of "secure and controllable" technologies. By privileging and subsidizing domestic products and technologies, these legislations/drafts have put under discussion the need for foreign firms to locally store data, disclose software source-codes to the government, as well as encryption keys in case of investigations and implement software and hardware backdoors for governmental access, particularly in the banking and insurance sector (MOZUR, 2015; DOU, 2016).

US tech giants have been put under legal and ideological pressure. Qualcomm was fined in U\$ 975 million in 2015 in the Chinese anti-monopoly law for higher than average royalty rates and for forcing combined licensing (MCCORMICK, 2015). As a result, the company paid the due, reduced royalties and later entered in a joint-venture with a Chinese firm. In 2013, Cisco, IBM, Google, Qualcomm, Intel, Apple, Microsoft and Oracle were named US' eight "guardian warriors", by the China Economic Weekly's cover, which had discreetly infiltrated in the country (ROSEN and BAO, 2013). It rapidly spread across the Chinese media with claims to the public for acquiring do-

16 Prior to 2013, China had made six investments in US semiconductor firms, totaling U\$214 million; from 2013 to late 2016, the rumored, attempted and successful investments were 27, totaling U\$37 billion (RHODIUM GROUP apud EUCCC, 2017).

17 The European Union Commercial Chamber in China (2017) concerns with Chinese acquisitions points to the Silex Microelectronics' case, a Sweden semiconductor company that ultimately felt in the hands of Beijing Navgness Integration, which subsequently entered in joint venture with the PLA. 
mestic products and technologies. Notwithstanding, there is a limit to these pressures as China still lags significantly behind in IC production and technology, depending on strategic partnerships with foreign firms to reduce its import dependency and absorb technology as well as to modernize its military and its capacity to face asymmetrical warfare.

Furthermore, Chinese technological achievements in the commercial sector are explicitly pursued in the attempt to raise military capabilities, concerning especially the US and Taiwan. China's IC industrial policies alarmed and prompted countering measures from major players. Without dispensing opposing Chinese "damaging" industrial policies, the US understand that maintaining its semiconductor leadership cannot be sustained on that, and has called for pursuing "moon shots", or ambitious challenges coordinating the innovation system (PCAST, 2017).

\section{CONCLUSION}

Despite neoliberal policies and rhetoric being impinged upon the world by the US and the EU over the last decades, industrial policy never was in question in strategic sectors. Significant technological semiconductor advancements are a crucial dimension of economic and military power. China has advanced several important steps in semiconductor production and in decreasing its dependency. Nonetheless, China is still distant from meeting its consumption needs and the technological frontier in design and manufacturing. Despite circumventing US export controls in SME, imports of state-of-the-art fab machinery were not made by Chinese headquartered firms (still two generations behind the leading-edge). Rather, they were made to establish facilities for companies as Intel and Samsung. In crucial SME, China is still much behind Japan, the US and Europe. This becomes more critical as Chinese headquartered semiconductor manufacturing firms push to reach leading-edge, given the security aspects referred before and the blockages derived from those goods subordinated to power strategies (strategic trade). However, China has its domestic market as bargaining power, the fact of being the major IC consumer and, consequently, the largest market for the production of semiconductors and their equipment. The ongoing strategy aims to take advantage of this technological opportunity, and it has already prompted strategic reactions from major players. 


\section{BIBLIOGRAPHIC REFERENCES}

ATTA, R. V.; SLUSARCZUK, M. M. G. The Tunnel at the end of the light: the future of the U.S. Semiconductor Industry. Issues in Science and Technology, v. 28, n. 3, 2012.

BINGHAM, R. D. Industrial policy American Style: From Hamilton to HDTV. New York: M. E. Sharpe, 1998.

CAS - US' SENATE COMMITTEE ON ARMED SERVICES. The Committee's investigation into counterfeit electronic parts in the department of defense supply chain. Washington: U.S. Government Printing Office, 2011.

CHANG, H.; ANDREONI, A. Industrial Policy in a changing world: basic principles, neglected issues and new challenges. Cambridge Journal of Economics 40 Years Conference, 2016.

CHANG, S. et al. Imitation to Innovation: technological catch-up strategy of late movers in emerging economies. SSRN Electronic Journal, 2015.

CHINA DAILY. Chip industry upgrades in Line with Xi Jinping's call to turn China into Manufacturer of Quality. The Straits Times, 19 Oct. 2017.

CHU, M. M. The East Asian computer chip war. London and New York: Routledge, 2013.

COLBERT, E. J. M. Security of cyber-physical systems. Journal of Cyber Security and Information Systems, v. 5, n.1, p. 40-47, 2017.

CS - CREDIT SUISSE. Asian semiconductor sector. Equity Research, 11 Jan. 2016.

DARPA - DEFENSE ADVANCED RESEARCH PROJECTS AGENCY. New Chips Ease Operations in Electromagnetic Environs. DARPA, 2016.

DARPA - DEFENSE ADVANCED RESEARCH PROJECTS AGENCY. Breakthrough Technologies for National Security. DARPA, 2015.

DICKSON, J. The case for synthesizing electronic warfare and cyber. The Cypher Brief, 2017.

DOD - DEPARTMENT OF DEFENSE. DOD Dictionary of Military and Associated Terms. Washington, DC: DOD, 2017.

DOU, E. Untangling China's cybersecurity laws. The Wall Street Journal, 03 Jun. 2016.

ERNST, D. China's bold strategy for semiconductors: zero-sum game or catalyst for cooperation? Honolulu: East-West Center and Waterloo: Centre for International Governance Innovation, 2016.

ERNST, D. From catching up to forging ahead: china's policies for semiconductors. Honolulu: East-West Center, 2015.

ERNST, D. Indigenous innovation and globalization: the challenge for China's standardization strategy. Honolulu: East-West Center, 2011.

EUCCC - EUROPEAN UNION CHAMBER OF COMMERCE IN CHINA. China Manufacturing 2025: Putting Industrial Policy Ahead of Market Forces. EUCCC, 2017.

GAO - US GOVERNMENT ACCOUNTABILITY OFFICE. Export Controls: rapid advances in China's semiconductor industry underscore need for fundamental U.S. policy review. Washington: US Congress, 2002. 
GAO. Offshoring: United States semiconductor and software industries increasingly produce in China and India. Washington, D.C.: US Congress, 2006.

GIBBONS-NEFF, T. This new DARPA chip could give U.S a leg up in electronic warfare. The Washington Post, 12 Jan. 2016.

IARPA - INTELLIGENCE ADVANCED RESEARCH PROJECTS ACTIVITY. IARPA Trusted Integrated Chips (TIC) Program. Federal Business Opportunities, 22 Jun. 2011.

ICINSIGHTS. Semiconductor R\&D Growth Slows in 2015. ICinsights, 20 Jan. 2016.

ICINSIGHTS. China's final chance to achieve its IC ambitions now underway. ICinsights, $16 \mathrm{Jul}$. 2016(a).

ICINSIGHTS. TowerJazz and SMIC's Sales Forecast to Surge in 2016. ICinsights, 23 Aug. 2016(b).

ICINSIGHTS. Five Top-20 Semiconductor Suppliers to Show Double-Digit Gains in 2016.ICinsights, 15 Nov. 2016(c).

ICINSIGHTS. U.S. companies still hold largest share of fabless company IC sales. ICinsights, 16 Mar. 2017.

ITA - INTERNATIONAL TRADE ADMINISTRATION. 2016 Top Markets Report: Semiconductors and Related Equipment. ITA, 2016.

JOHNSON, B. The U.S.-Japan semiconductor agreement: keeping up the managed trade agenda. Washington, D.C.: The Heritage Foundation, 1991.

KAGERMAN, H. et al. Recommendations for Implementing the Strategic Initiative INDUSTRIE 4.0. Frankfurt/Main: Platform Industrie 4.0, 2013.

KANIA, E. B. The PLA's potential breakthrough in high-power microwave weapons. The Diplomat, 2017.

KIM, S. R. The Korean System of innovation and the semiconductor industry: a governance perspective. SPRU/SEI Working Paper, 1996.

LI, Y. "State, market, and business enterprise: development of the Chinese integrated circuit foundries”. In: ZHOU, Y.; LAZONICK, W.; SUN, Y. (Eds.). China as an innovation nation. Oxford: Oxford University Press, 2016, p. 192-214.

MAJEROWICZ, E. "Relações econômicas entre China e Malásia: comércio, cadeias globais de produção e a indústria de semicondutores” In: CINTRA, M. A. M.; FILHO, E. B. S.; PINTO, E. C. (Orgs.). China em Transformação: dimensões econômicas e geopolíticas do desenvolvimento. Brasília: IPEA, 2015.

MAYS, S. K. Rapid advance: high technology in China in the global electronic age. Thesis (PhD in History) - Graduate School of Arts and Science, Columbia University, New York, 2013.

MCCORMICK, R. Qualcomm Fined \$975 Million by Chinese Anti-monopoly Regulators. The Verge, 09 Feb. 2015.

MILLARD, J. et al. Internationalisation and fragmentation of value chains and security of supply: case study on semiconductors. Brussels: European Commission; DG Enterprise and Industry, 2012.

MORRIS, P. R. A history of the world semiconductor industry. London: P. Peregrinus, 1990. 
MOZUR, P. New Rules in China Upset Western Tech Companies. The New York Times, 28 Jan. 2015.

NRC - NATIONAL RESEARCH COUNCIL. Rising to the Challenge: U.S. innovation policy for the global economy .Washington, D.C.: The National Academies Press, 2012.

OTA - U.S. CONGRESS, OFFICE OF TECHNOLOGY ASSESSMENT. Competing Economies: America, Europe, and the Pacific Rim. Washington, D.C.: U.S. Government Printing Office, 1991.

PCAST - THE PRESIDENT'S COUNCIL OF ADVISORS ON SCIENCE AND TECHNOLOGY. Ensuring long-term U.S. leadership in semiconductors. PCAST, 2017.

PFEIFFER, S. The vision of "Industrie 4.0" in the making - a case of future told, tamed, and traded. Nanoethics, v. 11, n.1, p. 107-121, 2017.

PHILIPP, J. China makes advances in space lasers, microwave weapons. The Epoch Times, 2017.

PILLSBURY, M. China's military strategy toward the US: A view from open sources. Washington, D.C.: National Defense University Press, 2001.

PWC - PRICE WATERHOUSE COOPERS. China's impact on the semiconductor industry. New York: PwC, 2004.

PWC - PRICE WATERHOUSE COOPERS. China's Impact on the Semiconductor Industry 2006 update. New York: PwC, 2007.

PWC - PRICE WATERHOUSE COOPERS.China's Impact on the Semiconductor Industry 2008 update. New York: PwC, 2008.

PWC - PRICE WATERHOUSE COOPERS. China's Impact on the Semiconductor Industry 2010 update. New York: PwC, 2010.

PWC - PRICE WATERHOUSE COOPERS. China's Impact on the Semiconductor Industry 2012 update. New York: PwC, 2012.

PWC - PRICE WATERHOUSE COOPERS. China's Impact on the Semiconductor Industry 2014 update. New York: PwC, 2015.

PWC - PRICE WATERHOUSE COOPERS. China's Impact on the Semiconductor Industry 2015 update. New York: PwC, 2016.

PWC - PRICE WATERHOUSE COOPERS. China's Impact on the Semiconductor Industry 2016 update. New York: PwC, 2017.

PWC - PRICE WATERHOUSE COOPERS. China's Impact on the Semiconductor Industry 2017 update. New York: PwC, 2017a.

RASIAH, R. Catch up in integrated circuits production: Malaysia compared to Korea and Taiwan. Inaugural Public Lecture of the Malaysian Centre of Regulatory Studies, University of Malaya, 13 Oct. 2010

RASIAH, R. et al. Explaining variations in semiconductor catch-up strategies in China, Korea, Malaysia and Taiwan. In: GLOBELICS CONFERENCE, 6, Mexico City, 22-24 Sept. 2008.

RAUD, M. China and Cyber: Attitudes, Strategies, Organisation. Tallinn: NATO Cooperative Cyber Defence Centre of Excellence, 2016. 
ROSEN, D. H.; BAO, B. Eight guardian warriors: PRISM and its implications for US businesses in China. Rhodium Group, Jul. 18, 2013.

SANGER, D. E.; BROAD, W. J. Hand of U.S. leaves North Korea’s missile program shaken. The New York Times, 2017.

SCHIESEL, S. Taking Aim at an Enemy's Chip.The New York Times, Feb. 20, 2003.

SIA - SEMICONDUCTOR INDUSTRY ASSOCIATION.2017 Factbook. SIA, May 2017.

SIA - SEMICONDUCTOR INDUSTRY ASSOCIATION.2016 Factbook. SIA, Mar. 2016.

SIA - SEMICONDUCTOR INDUSTRY ASSOCIATION. Beyond borders: the global semiconductor value chain. SIA, 2016a.

SIA - SEMICONDUCTOR INDUSTRY ASSOCIATION.2014 Factbook. SIA, 2014.

STATE COUNCIL. Made in China 2025. Beijing: State Council, 07 Jul. 2015.

STATE COUNCIL. China's Military Strategy. Beijing: State Council, 2015a.

STATE COUNCIL. Guideline for the promotion of the development of the national integrated circuit industry. Beijing: State Council, 2014.

TIANCHUN, Y. The IC Industry Needs Investment in the Scale of Trillions of RMB. USITO, 2014.

WEI, M. Interview on the background, significance and key points from the "Guidelines". USITO, 24 Jun. 2014. 